\title{
Phytochemical Profile and Evaluation of the Antimicrobial Activity of Echinodorus grandiflorus Crude Extract of the Leaves
}

Carla Indianara Bonetti, Mariana Dalmagro, Juliana Cristhina Friedrich, Douglas Rossi Jesus

Universidade Paranaense - UNIPAR, Unidade Universitária Toledo, curso de farmácia. Avenida Parigot de Souza, 3636, Jardim Prada, Toledo, Paraná, Brazil.

\section{Mariana Moraes Pinc}

Programa de Pós-graduação em Ciência Animal com ênfase em Bioativos. Laboratório de Pesquisa Pré Clínica de Produtos Naturais e Bioativos, Universidade Paranaense - UNIPAR, Praça Mascarenhas de Moraes, 4282, Umuarama, PR, Brazil

Odair Alberton (Corresponding Author), Emerson Luiz Botelho Lourenço

Programa de Pós-graduação em Plantas Medicinais e Fitoterápicos na Atenção Básica. Laboratório de Pesquisa Pré Clínica de Produtos Naturais e Bioativos, Universidade Paranaense - UNIPAR, Praça Mascarenhas de Moraes, 4282, Umuarama, PR, Brazil

E-mail: odair@prof.unipar.br

Received: July 10, $2020 \quad$ Accepted: August 6, $2020 \quad$ Published: August 10, 2020

doi:10.5296/jas.v8i4.17339

URL: https://doi.org/10.5296/jas.v8i4.17339

\begin{abstract}
Echinodorus grandiflorus has pharmacological properties due to its secondary metabolism, such as anti-inflammatory, antioxidant, diuretic, analgesic, anti-rheumatic, antihypertensive, and cardioprotective effects. The aim of this study was to determine the phytochemical profile and evaluate the antimicrobial activity of crude extract of E. grandiflorus form its leaves. In the analysis of the phytochemical profile, qualitative tests were performed to identify tannins, alkaloids, flavonoids, anthraquinones, steroids, triterpenes, saponins, polysaccharides, and coumarins. Antimicrobial tests were performed using the disk diffusion method and minimum inhibitory concentration (MIC) in 96-well microplates, using
\end{abstract}


hydroalcoholic crude extract obtained by maceration in the proportions 1:5 and 1:10. The higher content of crude extract was observed by maceration 1:5 (3.26\%). In phytochemical tests, the presence of tannins, alkaloids, flavonoids, and saponins was detected. The microbial strains evaluated were Staphylococcus aureus, S. epidermidis, Lactobacillus casei, Bacillus cereus, Escherichia coli, Pseudomonas aeruginosa, and Candida albicans. The antimicrobial activity of crude extract has not apparent against the tested organisms. It is concluded that the crude extract present several phytochemical, however did not show antimicrobial activity, and furthermore studies should be carried out researching isolated chemical compounds and the antimicrobial activity leaves crude extract of Echinodorus grandiflorus plant.

Keywords: plant metabolism; phytochemical screening; medical plant

\section{Introduction}

The need to know the chemical constituents of the plant provided studies focused on plant biology, which demonstrated the presence of primary and secondary metabolites in plants (Lôbo et al., 2010). The primary metabolism is composed of a process little variable to most vegetables and which leads to the synthesis of cellulose, lignin, carbohydrates, proteins, lipids, and nucleic acids. In contrast, the secondary metabolites are present in low concentrations and are stored in specific cells of the plant in which allow its adaptation and probability of survival in the environment (Penã et al., 2016; Pereira; Cardoso, 2012).

The classification of secondary metabolites is based on the biosynthetic route where they are produced, being divided into three main groups of molecules: phenolic, terpenic and steroid compounds, and alkaloids (Fumagali et al., 2008). Secondary plant metabolites stand out in the field of pharmacology due to their biological effects on the health of the human species, and may have antimicrobial, anti-inflammatory, antioxidant, diuretic, analgesic, anti-rheumatic, antihypertensive and anti-cholesterolemic activity (Pereira; Cardoso, 2012).

Extractive methods for obtaining secondary metabolites include maceration, infusion, percolation, decoction, hot continuous extraction (Soxhlet), counter-current extraction, microwave-assisted extraction, ultrasound, supercritical fluid and turbolysis. In addition to extractive methods, there are several factors that influence extraction, such as the part of the plant material used, its origin, the degree of processing, the particle size, the solvent used, the extraction time, temperature, polarity, and concentration of the solvent. The solvent used and the polarity can affect the transfer of electrons and hydrogen atoms, which is an important aspect of the extraction of polyphenols (Oliveira et al., 2016).

Studies have demonstrated the antimicrobial activity of plant extracts from different plant species. Phytotherapy is inserted as one of the main alternatives due to the easier access by the population, widespread use, inexpensive cost and efficiency comparable to synthetic drugs. Plant extracts can reveal great potential against diseases through the synergistic or individual action of compounds from their secondary metabolism, such as flavonoids, tannins, carotenoids, glycosides, alkaloids and others (Baptista, 2012). The great interest in herbal medicines is explained in part by the indiscriminate use of antibiotics that have selected multidrug-resistant microorganisms and, consequently, the need to seek new antimicrobial 
substances (Rozatto, 2012).

Among the main microorganisms that are resistant to antibiotics, there are methicillin-resistant Staphylococcus aureus and S. pneumoniae not susceptible to penicillin. Vancomycin-resistant Enterococcus, Broad-spectrum beta-lactamase-producing Enterobacteriaceae, Pseudomonas aeruginosa resistant to macrolides and Escherichia coli resistant to streptogramins (Costa; Silva Junior, 2017).

Recent studies have demonstrated the antimicrobial activity of different plant extracts. Among them, the extracts of Echinodorus grandiflorus (Alismataceae), popularly known as "leather hat", grows in several humid soils as a vegetative support cover (Marques et al., 2017). The used parts of the plant are the leaves that are usually administered orally by aqueous infusion. Pharmacological activities described in the literature indicate its effectiveness as anti-inflammatory, antioxidant, antiedematogenic, antiproliferative, diuretic, analgesic, anti-rheumatic, antihypertensive and with cardioprotective effects (Pimenta et al., 2006; Garcia et al., 2010; Prando et al., 2015; Coelho et al., 2017: Marques et al., 2017: Gasparotto et al., 2018, 2019; Gomes et al., 2020).

Studies using aqueous crude extract of the leaves of E. grandiflorus have shown a low potential antimicrobial species, acting on some strains of microorganisms (Maques et al., 2017; Brugiolo, 2010). No study has been reported on the antimicrobial activity using hydroalcoholic crude extract of its leaves. Thus, this study aims to determine the phytochemical profile and evaluate the antimicrobial activity of E. grandiflorus crude extract from the leaves under different methods.

\section{Materials and Methods}

\subsection{Collection and Preparation of the Vegetable Sample}

The botanical material was collected at the Medicinal Garden of UNIPAR (Universidade

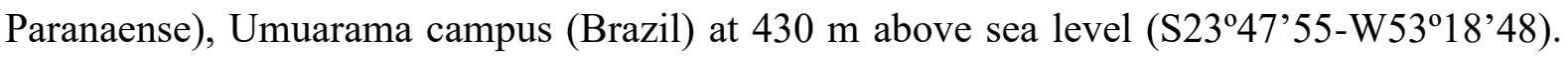
The leaves were collected from September to December 2017. The plant material was dried in greenhouses with forced air circulation at $37^{\circ} \mathrm{C}$ for five days. After drying, the material was subjected to crushing. The spraying was performed in industrial crushers, and then the material was packed in double bags, made of polyethylene on the inside and Kraft paper on the outside, until the preparation of the crude extracts. A specimen of the species under study, identified by professor Dr. Mariza Barion Romagnolo, is cataloged under number 2.230 in the Herbarium of the Medicinal Garden of UNIPAR campus Umuarama - PR.

\subsection{Phytochemical Screening}

Phytochemical tests consisted of simple qualitative chemical reactions, performed in triplicate, which demonstrated the presence of organic compounds. The analyzes for the determination of tannins, alkaloids, flavonoids, anthraquinones, saponins, steroids and triterpenes, were based on the methodology described by the Brazilian Society of Pharmacognosy (2009), with changes. For the polysaccharide test and the determination of coumarins, the protocol mentioned by Gonçalves; Lima, (2016) was used. For the 
determination of total flavonoids, a spectrometric method proposed by Woisky; Salatino, (1998), was used.

\subsubsection{Tannins}

In a beaker, $5 \mathrm{~g}$ of powdered E. grandiflorus were boiled together with $50 \mathrm{~mL}$ of distilled water for 15 minutes. This filtrate was then divided into four test tubes duly identified, with 2 $\mathrm{mL}$ of the crude hydroalcoholic extract being inserted in the first and second tubes, and $5 \mathrm{~mL}$ of the extract in the third and fourth tubes. In the first tube, 2 drops of dilute hydrochloric acid $(\mathrm{HCl})$ and $2.5 \%$ gelatin solution were added dropwise. The positive result was due to the formation the precipitate. In the second tube, $10 \mathrm{~mL}$ of distilled water and 2 to 3 drops of $1 \%$ ferric chloride $\left(\mathrm{FeCl}_{3}\right)$ in methanol were inserted. The result was given through coloring, where the blue color determined the presence of hydrolyzable or gallic tannins and the green color, condensed or catechic tannins. In the third tube, $10 \mathrm{~mL}$ of $10 \%$ acetic acid solution $\left(\mathrm{C}_{2} \mathrm{H}_{4} \mathrm{O}_{2}\right)$ and $5 \mathrm{~mL}$ of $10 \%$ lead acetate solution $\left[\mathrm{Pb}\left(\mathrm{C}_{2} \mathrm{H}_{3} \mathrm{O}_{2}\right)_{2}\right]$ were added. The presence of hydrolyzable tannins was due to the formation of an off-white precipitate. The fourth tube was used as a control.

\subsubsection{Saponins}

In a beaker, $2 \mathrm{~g}$ of powdered E. grandiflorus were boiled with $20 \mathrm{~mL}$ of distilled water for 2 minutes. After cooling, the mixture was filtered and $15 \mathrm{~mL}$ of the filtrate was transferred to a test tube. From the first tube, $5 \mathrm{~mL}$ of the extract was removed and transferred to a second tube, adding $5 \mathrm{~mL}$ of distilled water. From the second tube, $5 \mathrm{~mL}$ was removed and placed in a third tube, adding $5 \mathrm{~mL}$ of distilled water. Then, the three tubes were quickly shaken for 15 seconds. Foaming for more than 15 minutes confirmed the presence of saponins.

\subsubsection{Steroids / Triterpenes}

In a beaker, containing $2 \mathrm{~g}$ of powdered E. grandiflorus, $20 \mathrm{~mL}$ of $70 \%$ ethanol were added, the boil was carried out for 2 minutes, afterward it was filtered through cotton and $5 \mathrm{~mL}$ of the extract was transferred to a crucible. Then, the extract was evaporated in a water bath (FISATOM, model 550), until a dry residue was obtained, where $0.5 \mathrm{~mL}$ of acetic anhydride $\left[\left(\mathrm{CH}_{3} \mathrm{CO}\right)_{2} \mathrm{O}\right]$ was added, stirring with a stick, followed by the addition $0.5 \mathrm{~mL}$ of concentrated sulfuric acid $\left(\mathrm{H}_{2} \mathrm{SO}_{4}\right)$. After the color was observed, being blue or green for steroids and lilac, purple or reddish-brown for triterpenes.

\subsubsection{Alkaloids}

The search for these compounds was based on the precipitation method using the General Reactors of Alcaloides (RGA): Bertrand, Bouchardat, Dragendorff and Mayer, verifying the formation of insoluble and flocculate precipitate. In a beaker, containing $2 \mathrm{~g}$ of $E$. grandiflorus powder, $20 \mathrm{~mL}$ of $1 \%$ hydrochloric acid $(\mathrm{HCl})$ were added, and then the mixture was heated for 2 minutes, followed by cotton filtration. The filtrate was distributed in 4 test tubes ( $3 \mathrm{~mL}$ per tube), and then 2 drops of each RGA was added, observing the occurrence of the precipitate. 


\subsubsection{Flavonoids}

In a beaker, $1 \mathrm{~g}$ of powdered E. grandiflorus in a water bath was heated with $10 \mathrm{~mL}$ of $70 \%$ ethanol solution for 2 minutes, immediately after the cotton filtration. Then, in a test tube, containing $2 \mathrm{~mL}$ of the alcoholic extract, six fragments of metallic magnesium were added. Afterward, $1 \mathrm{~mL}$ of concentrated hydrochloric acid was added. In the presence of these compounds, the appearance of pink to red color was observed.

\subsubsection{Total Flavonoids}

$150 \mu \mathrm{L}$ of the fractionated extract was transferred to a test tube wrapped in aluminum foil containing $3,850 \mu \mathrm{L}$ of methyl alcohol and $1,000 \mu \mathrm{L}$ of $5 \%$ aluminum chloride methanolic solution. After 30 minutes in the dark, a reading was performed on a Pro-Analysis spectrophotometer (UV-1600/1800) at $425 \mathrm{~nm}$ against white. Total flavonoids were quantified using the standard Quercetin curve. The samples were evaluated in triplicate and the values expressed as mean \pm standard deviation.

\subsubsection{Quercetin Pattern Curve}

$10 \mathrm{mg}$ of quercetin were weighed in a $100 \mathrm{~mL}$ volumetric flask and the volume was made up to volume with methanol. From this stock solution, $10 \mathrm{~mL}$ flasks were taken and 5 dilutions were made. The following concentrations were removed respectively: $0.25 \%, 0.5 \%, 1 \%, 2 \%$ and $4 \%$. All of these dilutions were completed in a $10 \mathrm{~mL}$ volumetric flask with methanol until the meniscus was completed and subsequently, $4 \mathrm{~mL}$ of the solution $+1 \mathrm{~mL}$ of $5 \%$ aluminum chloride was taken and read on a Pro-Analysis spectrophotometer (UV-1600/1800) at $425 \mathrm{~nm}$ against white.

\subsubsection{Anthraquinones}

In a beaker containing $0.2 \mathrm{~g}$ of powdered E. grandiflorus, $10 \mathrm{~mL}$ of 2 Normal sulfuric acid $(\mathrm{N})$ was added and boiled for 2 minutes. After cooling, the extract was filtered into a separating funnel. Then $10 \mathrm{~mL}$ of ethyl ether were added, the ether layer was stirred and separated into a test tube. The yellow color suggested the presence of anthraquinones. Subsequently, $2 \mathrm{~mL}$ of $2 \mathrm{~N}$ aqueous sodium hydroxide solution was added and stirred. After the separation of the phases, the presence of a pink or red layer was observed, and the colorless ethereal layer, confirming the presence of anthraquinones.

\subsubsection{Polysaccharides}

In the research, $2 \mathrm{~mL}$ of the crude hydroalcoholic extract was added in a test tube, adding 2 $\mathrm{mL}$ of Lugol. The appearance of a bluish color indicated the presence of polysaccharides.

\subsubsection{Coumarins}

Two $\mathrm{mL}$ of the crude hydroalcoholic extract were inserted in a test tube, which was then sealed with a filter paper impregnated with $10 \%$ sodium hydroxide solution $(\mathrm{NaOH})$. The tube was taken to a water bath at $100^{\circ} \mathrm{C}$ for 10 minutes. The filter paper was removed from the tube and examined using ultraviolet (UV) light at $100 \mathrm{~nm}$ wavelength. The presence of coumarins was identified by yellow or green fluorescence. 


\subsection{Extraction Methods}

\subsubsection{Preparation of Plant Extracts}

Following the methodology of Oliveira et al. (2016), for the five proposed extractive methods, the same proportion of the vegetable drug with the extracting solvent was used, which went from $10 \mathrm{~g}$ to $100 \mathrm{~mL}$. Two different solvents were used in the extractions, the first using $90 \%$ ethanol and the second using 70\% hydroalcoholic solvent and all 10 plant extracts were filtered and concentrated in a rotary evaporator.

\subsection{Cold Methods}

\subsubsection{Turbolysis}

The crude extract by turbolysis was prepared using blender equipment for a period of 10 minutes at 4,000 rpm at room temperature.

\subsubsection{Maceration}

The crude extract obtained by maceration was prepared using amber flasks sealed for a period of 7 days without lighting, shaking once a day.

\subsection{Hot Methods}

\subsubsection{Decoction}

The crude extract by decoction was prepared using amber flasks in a water bath at $90{ }^{\circ} \mathrm{C}$ for a period of 15 minutes. Ensuring the boiling of the solvent used.

\subsubsection{Infusion}

For these extractions, the solvents were brought to the boiling temperature, and, after this process, they were poured into amber flasks that contained the plant material and capped for 30 minutes.

\subsubsection{Soxhlet}

For the elaboration of the crude extract obtained by Soxhlet, the clarity of the extractor solvent was observed, which characterized it as the total extraction, totaling approximately 8 hours of extraction.

\subsection{Determination of Dry Residue}

One $\mathrm{mL}$ of each extract was exactly measured and transferred to porcelain capsules, previously tared. The capsules were placed in an oven at a temperature of $105{ }^{\circ} \mathrm{C}$, until dryness and constant weight. The capsules were weighed again and the solids content in $10 \mathrm{~g}$ of the plant drug and the standard deviation were calculated.

\subsection{Microorganisms}

The microorganisms used in the tests were Gram-positive bacteria S. aureus, S. epidermidis, Lactobacillus casei and B. cereus and Gram-negative E. coli and Pseudomonas aeruginosa 
and the yeast $C$. albicans. For the tests performed, the microorganisms were grown separately in plates containing Müeller Hinton broth for the bacteria and Sabouraud agar for the fungus, being incubated in a greenhouse at $36{ }^{\circ} \mathrm{C}$ for 24 hours. After this period, a standard suspension of each species of microorganisms in logarithmic growth phase (LOG) was prepared, using $0.9 \%$ sterile saline solution, comparing the turbidity of the suspension with the 0.5 scale of Mac Farland.

\subsection{Determination of the Minimum Inhibitory Concentration (MIC)}

Following the methodology described by Colacite, (2015), with modifications, a microplate with 96 wells were used, with $100 \mu \mathrm{L}$ of Müller Hinton broth being added to each well. In the first wells, $100 \mu \mathrm{L}$ of the stock solutions of $40,000 \mu \mathrm{g} \mathrm{mL}^{-1}$ of the extract and fractions were added, obtaining the concentration of $20,000 \mu \mathrm{g} \mathrm{mL} \mathrm{m}^{-1}$. Serial dilution was carried out in the eight consecutive wells, removing $100 \mu \mathrm{L}$ from the well of highest concentration to the next well, until reaching a concentration of $39.06 \mu \mathrm{g} \mathrm{mL}^{-1}$. From the standard suspensions of the bacterial species used in the study, a 1:10 dilution was performed and the equivalent of $5 \mu \mathrm{L}$ was pipetted into each well. For the negative control, in one of the wells, $100 \mu \mathrm{L}$ of the Müller Hinton broth and $100 \mu \mathrm{L}$ of the extract in the highest concentration were added. And for the positive control, $100 \mu \mathrm{L}$ of Müller Hinton broth and $5 \mu \mathrm{L}$ of bacterial suspension were pipetted. The plates, properly identified, were incubated in an oven at $36{ }^{\circ} \mathrm{C}$ for 24 hours. The MIC was determined by the highest dilution that inhibited microbial growth, being characterized by the absence of turbidity in the respective well. The tests were performed in duplicate.

\subsection{Antifungal Activity}

According to the method described by Desoti et al. (2011), with modifications, plates containing Sabouraud agar were used, with about $100 \mu \mathrm{L}$ of the standard suspension of the fungal species being added with the aid of a Drigalski loop. White disks and sterile roses with a diameter of $6 \mathrm{~mm}$ were applied on the agar, equidistant. From the stock solution of 40,000 $\mu \mathrm{g} \mathrm{mL} \mathrm{m}^{-1}$ of the extract, a serial dilution was performed, obtaining the concentrations of $20,000,10,000,5,000,2,500,1,250,625,312.5,156.25,78.12$ and $39.06 \mu \mathrm{gL}^{-1}$. One of the disks was pipetted with $10 \mu \mathrm{L}$ of sterile $0.9 \%$ saline as a negative control. For the positive control, $10 \mu \mathrm{L}$ of the extract was used in the highest concentration. In the remaining discs, 10 $\mu \mathrm{L}$ of the crude extract diluted in different concentrations were pipetted. The plates were incubated in an oven at $27{ }^{\circ} \mathrm{C}$ for 24 hours and the determination of the antifungal activity of the extracts was verified by measuring the inhibition halos formed in millimeters ( $\mathrm{mm}$ ), using a caliper. The tests were performed in triplicate.

\subsection{Statistical Analysis}

All trials followed a completely randomized design, conducted in triplicate. The results were submitted to analysis of variance (ANOVA) and the significant differences $(p \leq 0.05)$ determined by the Scott-Knott test using SISVAR - DEX - UFLA software. 


\section{Macrothink}

\section{Results and Discussion}

Secondary metabolites are examples of compounds that are produced in response to several environmental factors. These have restricted distribution, some are exclusive to a species or a group of related species, the formation of these occurs through biosynthesis pathways that derive from the primary metabolism of carbon, via the main intermediates, shikimic acid and acetate (Rockenbach et al., 2018).

\subsection{Phytochemical Tests Were Performed Through Simple Qualitative Analysis}

Hydroalcoholic extract of E. grandiflorus was made from crushed dry leaves, positive results were obtained for tannins, saponins, flavonoids and alkaloids, as shown in Table 1. These findings are consistent with the results found by Brugiolo, (2010), which show the presence of alkaloids, flavonoids, saponins, tannins, in addition to glycides, terpenes, triterpenes and cardiotonic glycosides.

Brito (2014) in a phytochemical analysis used hydroalcoholic extract from the leaves of $E$. grandiflorus and detected the presence of tannins, flavones, xanthones, chalcones, auronas, saponins and alkaloids. Gasparotto et al. $(2018$; 2019) detected the presence of different classes of secondary metabolites, including alkaloids, tannins, terpenoids and saponins. These findings corroborate the results found in the research.

Table 1. Phytochemical screening of the hydroalcoholic extract of leaves of Echinodorus grandiflorus

\begin{tabular}{llc}
\hline Class of phytochemicals & & Results \\
\hline Tannins & Gelatine & ++ \\
& Ferric Chloride & ++ \\
& Lead Acetate & +++ \\
Alkaloids & Bertrand & ++ \\
& Bouchardat & ++ \\
& Dragendorff & ++ \\
& Mayer & + \\
Flavonoids & Metallic magnesium & ++ \\
& Concentrated HCl & - \\
Ethyl alcohol & - \\
Steroids & 2N sodium hydroxide & - \\
Triterpenes & & +++ \\
Saponins & & - \\
Polysaccharides & & - \\
Coumarinas & & \\
\hline
\end{tabular}

The $(+)$ sign indicates the presence of the phytochemical, being: $(+++)$ Very; $(++)$ Medium; (+) Little; (-) Absent.

For cross identification, comparison standards were used, in which the following were used: 


\section{Macrothink}

Tannins: Barbatimão (Stryphnodendron adstringens); Alcaloides: Guaraná (Paullinia cupana); Flavonoids: Faveiro (Dimorphandra mollis); Saponins: Yerba Mate (Ilex paraguariensis).

\subsection{Tannins}

Divided into two structural groups, tannins can be classified into hydrolysables and condensates. They are polyphenols synthesized by plants and have the ability to precipitate proteins (Alessandro et al., 2018). Pharmacologically, tannins have anti-inflammatory, antiallergic, antioxidant, antimicrobial, antithrombotic and cardiovascular properties (Siqueira, 2011). Hydrolyzable tannins have ester bonds and have a greater capacity to bind to proteins, they can be degraded by chemical or enzymatic hydrolysis in various structural units that compose them, decreasing or eliminating the ability to bind with proteins. Condensed tannins, on the other hand, are not degraded by natural enzymatic processes and their high molecular weight decreases their ability to bind with proteins, promoting red coloring in several plants (Mezzomo et al., 2015). The presence of tannins was found in the phytochemical study, as shown in Figure 1.



Figure 1. Phytochemical determination of tannins. Tube 1 (extract $+2.5 \%$ gelatin solution), Tube 2 (extract + distilled water $+1 \%$ ferric chloride solution in methanol), Tube 3 (extract + $10 \%$ acetic acid solution + acetate solution $10 \%$ lead), Tube 4 (pure extract)

\subsection{Flavonoids}

Considered one of the most important groups of organic compounds obtained from the secondary metabolism of plants, flavonoids are major in Echinodorus and act in the protection of the plant against the action of oxidizing agents, ultraviolet radiation (UV), microorganisms and enzymatic inhibition (Flambó, 2013). In addition to helping the plant, flavonoids also have the potential for pharmacological activities such as antioxidants, antimicrobial, anticarcinogenic, cardiovascular and anti-inflammatory (Torres et al., 2018). Figure 2 indicates the presence of this compound due to the formation of a reddish-pink color. 


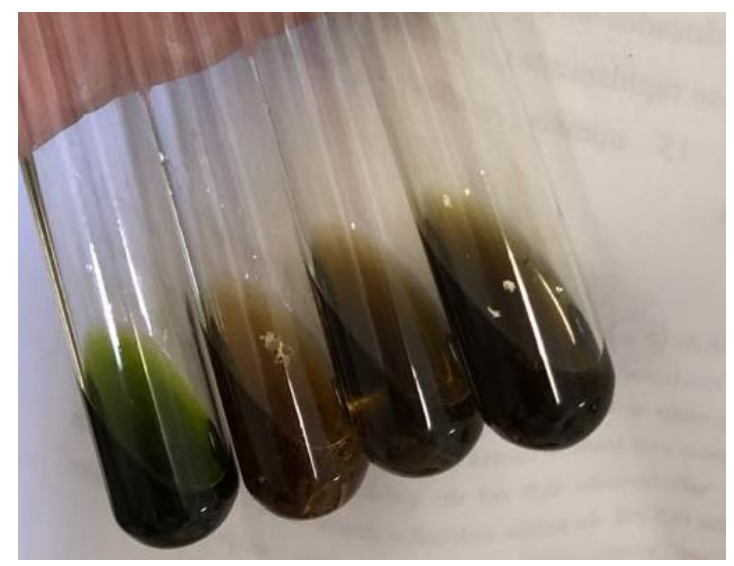

Figure 2. Phytochemical determination of flavonoids. Tube 1: Control; Tube 2, 3 and 4: Presence of flavonoids performed in triplicate

\subsection{Total Flavonoids}

The content of Total Flavonoids was obtained by spectrometry at $\lambda=425 \mathrm{~nm}$ (Woisky; Salatino, 1998), the standard curve obtained was $y=3.5195 x-0.0051-R^{2}=1$.

Total flavonoids were quantified using the standard Quercetin curve, where $1.20 \pm 0.001 \%$ of flavonoids were obtained (Table 2). The samples were evaluated in triplicate.

Table 2. Results for the determination of total flavonoids expressed in Quercitin in the ethanolic extract of Echinodorus grandiflorus

\begin{tabular}{llllll}
\hline & Abs & {$\left[\mathrm{mg} \mathrm{mL}^{-1}\right.$} & Dilution & $\mathrm{Mg}$ & $\%$ \\
\hline 1.1 & 2.124 & 0.604944 & 10 & 6.04944 & 1.20988 \\
1.2 & 2.125 & 0.605228 & 10 & 6.05228 & 1.21042 \\
1.3 & 2.120 & 0.603807 & 10 & 6.03807 & 1.20762 \\
Average & & & & & 1.20932 \\
SD & & & & & 0.00150 \\
\hline
\end{tabular}

There are no studies on the quantification of flavonoids in E. grandiflorus, however Vitex megapotamica is considered a standard plant for flavonoids, being present derivatives of primary flavonoids such as casticin, orientin and isovitexine, these are found in leaves, fruits and flowers, it has in around 4\% of total flavonoids (Brum, 2012).

\subsection{Alkaloids}

Alkaloids are nitrogen compounds that are pharmacologically active and are found mainly in angiosperms, most of which have an alkaline character (Santos; Mello, 2010). It has been 


\section{Macrothink}

observed that many plants that produce alkaloids are avoided by animals and insects in their diet, this is certainly due to their toxicity or the fact that most alkaloids have a bitter taste (Lima, 2011). Biologically, alkaloids act on opiate neurotransmitter systems. These are widely used in hypotension, vasoconstriction, respiratory activator, anesthesia, sedative and muscle relaxant. In addition, they are responsible for the hallucinogenic effects of tobacco (Oliveira; Almeida, 2016). According to Figure 3, the presence of alkaloids was confirmed by the formation of a precipitate.

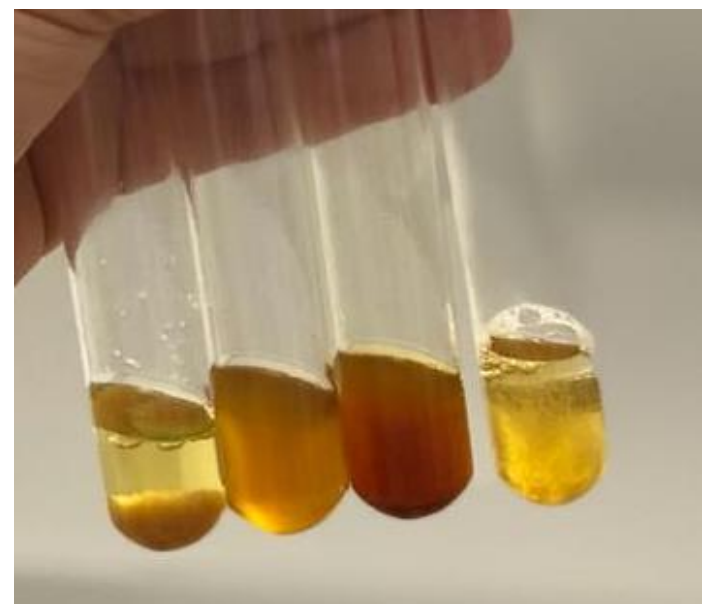

Figure 3. Phytochemical determination of alkaloids

\subsection{Saponins}

Saponins are glycosidic compounds formed by aglycone linked to sugar molecules (Rebelo, 2011). These substances have the characteristic of forming foam when stirred in water, this being one of the processes used in their identification. Saponins are essential for plant protection, also having pharmacological properties, as they have the ability to complex with steroids so they are used as an anti-inflammatory, diuretic, expectorant, hypocholesterolemic and antiviral (Castejon, 2011). Figure 4 shows the presence of saponins, characterized by the formation of abundant and long-lasting foam, averaging $3.1 \mathrm{~cm}$ after 15 minutes. 


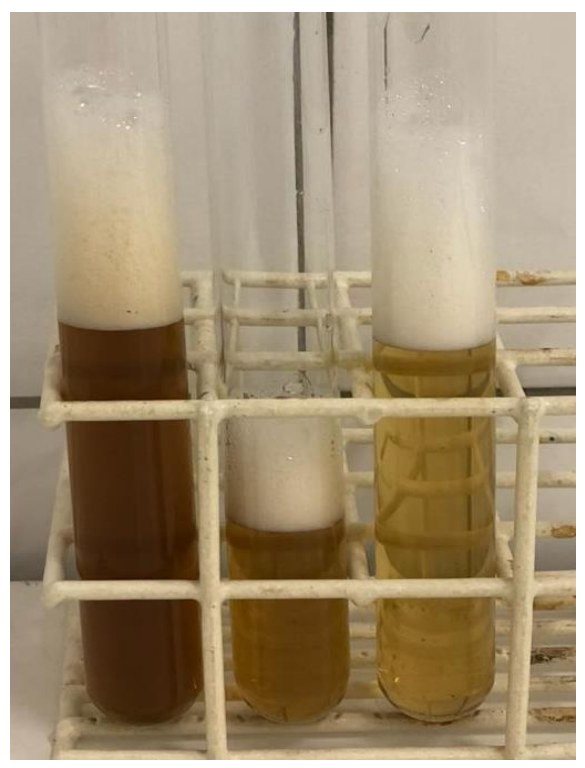

Figure 4. Phytochemical determination of saponin

\subsection{Extractive Methods}

The extraction aims to remove constituents from a natural raw material, being carried out constantly with liquid solvents. It is a physical-chemical mass transfer operation, where soluble and volatile solids can be extracted by maintaining contact between the solvent and the solids (Simões et al., 2017).

The content of extracts from previously dried and crushed leaves are shown in Figure 5. Considering the results, it can be seen that the extractive method directly influences the contents of the extracts and that, in addition to the method used, the solvent also influences the final content of the extraction.

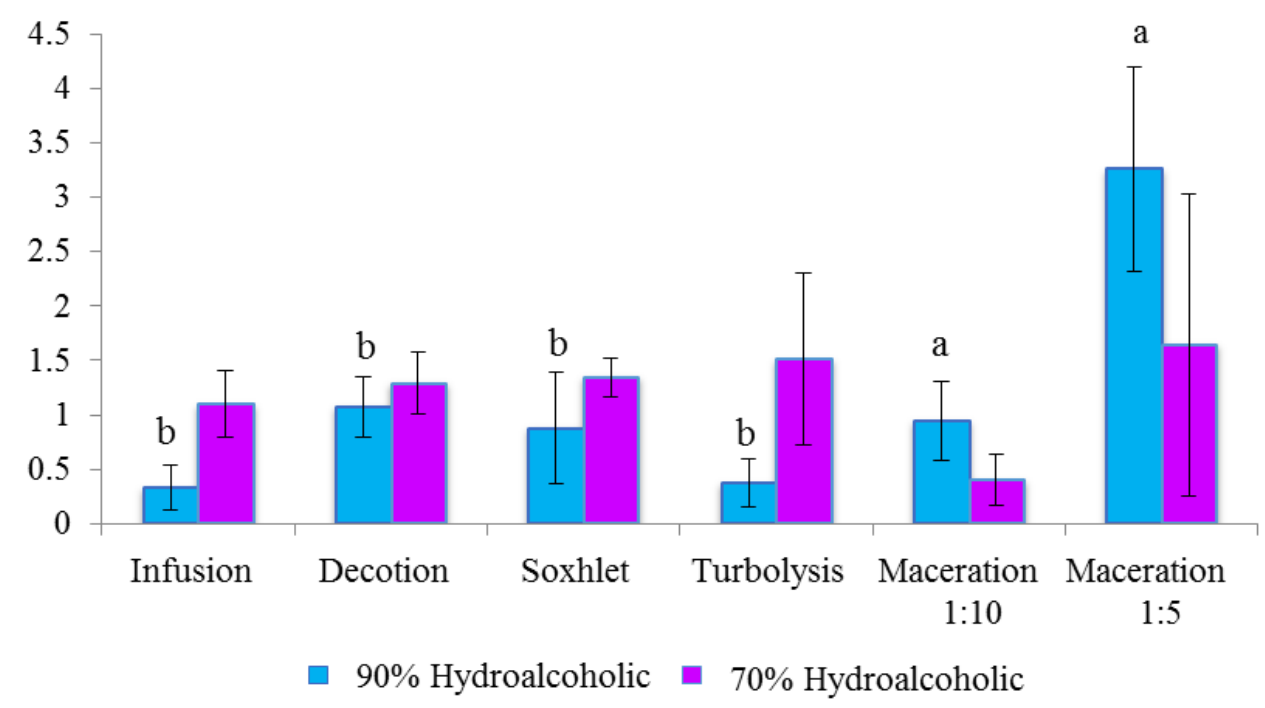

Figure 5. Content (\%) of dry residue output under different extractive methods. (mean \pm standard deviation) 


\section{Macrothink Institute ${ }^{\text {TM }}$}

Statistically 1:5 maceration showed higher response with $90 \%$ hydroalcoholic solvent and $70 \%$ hydroalcoholic solvent. This is due to a higher proportion of extract and a smaller amount of solvent compared to other extraction methods. Taking into account both solvents used in the extraction, it is observed that the $70 \%$ hydroalcoholic solvent has a better content in practically all extractive methods, except for 1:10 and 1:5 maceration.

This factor demonstrates that the hydroalcoholic solvent is more selective for the extraction of the metabolites present in the leaves of E. grandiflorus. Oliveira et al., (2016) identified the presence of tannins and flavonoids groups of secondary metabolism with a more polar character.

The lower content of hot extractions may be due to the fact that many substances are thermolabile and others may undergo irreversible structural changes at high temperatures (Tiwari et al., 2011).

\subsection{Antibacterial and Antifungal Activity}

For the antimicrobial activity, the extraction with the highest content was used, which was maceration 1:5 and later maceration 1:10 was used, both were resuspended with water.

In the MIC test performed on 96 well microplates, it was found that there was no inhibition of the growth of the tested bacteria, that is, turbidity occurred in all the analyzed concentrations as shown in Figure 6.

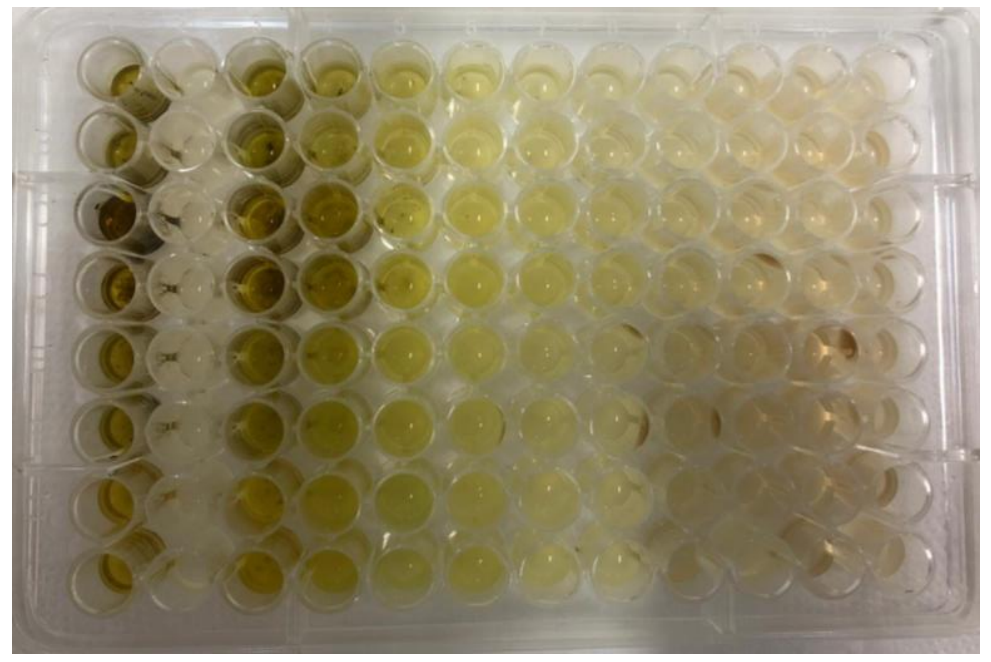

Figure 6.96 well plate showing turbidity

Babicz et al. (2006), through the disk diffusion test, observed the antimicrobial activity of $E$. grandiflorus against Gram-positive and Gram-negative bacteria, with aqueous extract and methanolic extract of the leaves, activity was obtained on S. aureus. He also observed antimicrobial activity in the acetonic extract of E. grandiflorus.

According to Baptista, (2013) did not identify the antimicrobial activity of E. grandiflorus. According to Teixeira, (2014), when analyzing the antimicrobial activity of the dry extract of E. grandiflorus found that there was no activity for the bacteria tested. 


\section{Macrothink Institute ${ }^{\mathrm{TM}}$}

In the evaluation of antifungal activity there was also no inhibition of the growth of the yeast C. albicans, there was growth throughout the disc method (Figure 7), and was not done by the MIC test performed on 96 well microplates.

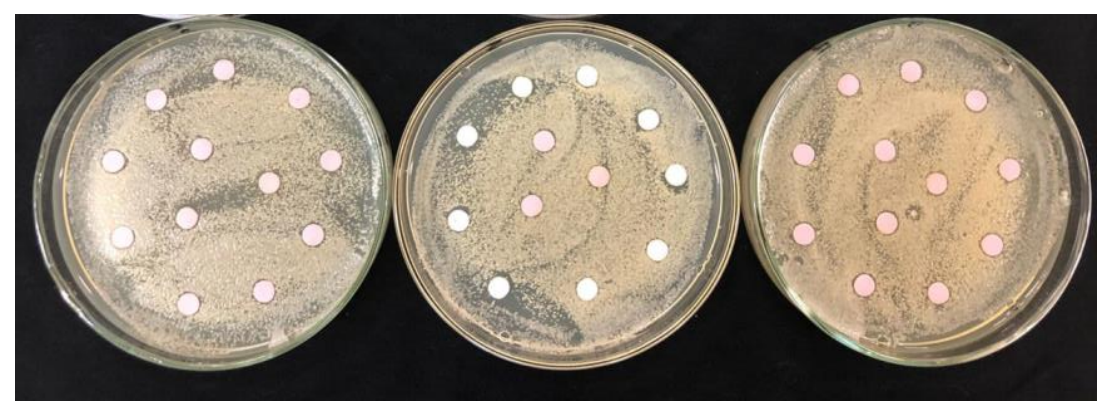

Figure 7. Yeast growth throughout the disc method

\section{Conclusion}

The results show that the extraction method and the hydroalcoholic degree of the solvent directly influence the sample content, but higher contents in the extraction process do not necessarily mean greater efficiency.

In relation to phytochemical screening, compounds obtained from plant metabolism are consistent with the literature found, with the presence of tannins, flavonoids, alkaloids and saponins being identified.

The crude extract present several phytochemical, however did not show antimicrobial activity, and furthermore studies should be carried out researching isolated chemical compounds and the antimicrobial activity leaves crude extract of Echinodorus grandiflorus plant.

\section{References}

Alessandro, O. D. et al. (2018). Sintesis y caracterización de "tanatos" de lantano como inhibidores de lacorrosión. Departamento de Química, Facultad de Ciencias Exactas, Universidad Nacional de La Plata, 23(2). https://doi.org/10.1590/s1517-707620180002.0394

Babicz, I. et al. (2006). Estudo da composição química e avaliação de atividade antimicrobiana de extratos obtidos a partir de Echinodorus macrophyllus. Anais. XXIX reunião Anual da Sociedade Brasileira de Química, Águas de Lindóia.

Baptista, M. B. L. (2012). Avaliação in vitro da atividade antimicrobiana e antioxidante de extratos fitoterápicos produzidos na pastoral da saúde de venda nova do imigrante - ES. Dissertação (Mestrado em Biotecnologia) - Centro de ciências da saúde - Universidade Federal do Espírito Santo, Vitória. 90-95.

Baptista, M. G. F. M. (2013). Mecanismos de resistência aos antibióticos. Dissertação (Mestrado em Ciências Farmacêuticas) - Faculdade de Ciências e Tecnologias da Saúde Universidade Lusófona de Humanidades e Tecnologia, Lisboa. 50-51. 
Brito, V. R. (2014). Controle de qualidade de amostras da espécie Echinodorus macrophyllus comercializadas no munícipio de Palmas - TO. Monografia (Ciências Farmacêuticas) Centro Universitário Luterano de Palmas, Palmas. 40-42.

Brugiolo, S. S. S. (2010). Avaliação da toxicidade do extrato aquoso liofilizado de Chapéu-de-Couro (Echinodorus grandiflorus) em ratas prenhes. Tese (Doutorado do programa de pós-graduação em saúde) - Universidade Federal de Juiz de Fora Juiz de Fora. 84-86.

Brum, T. F. (2012). Metabólitos secundários, composição química e atividade antioxidante do óleo essencial e das folhas de Vitex megapotamica (Sprengel) Moldenke. Dissertação (Mestrado em ciências farmacêuticas) - Universidade Federal de Santa Maria, Santa Maria. 103-105. https://doi.org/10.5902/223658343088

Castejon, F. V. (2011). Taninos e Saponinas. Dissertação (Mestrado em ciência animal e zootecnia) - Universidade Federal de Goiás, Goiânia. 21-28.

Coelho A. P. D. et al. (2017) Genotoxic and antiproliferative potential of extracts of Echinodorus grandiflorus and Sagittaria montevidensis (Alismataceae). Caryologia, 70(1), 82-91. https://doi.org/10.1080/00087114.2016.1275932

Colacite, J. (2015). Triagem fitoquímica, análise antimicrobiana e citotóxica e dos extratos das plantas: Schinus terebinthifolia, Maytenus ilicifolia REISSEK, Tabebuia avellanedae, Anadenanthera colubrina (Vell.) BRENAN. Revista Saúde e Pesquisa, 8(3), 509-516. https://doi.org/10.17765/1983-1870.2015v8n3p509-516

Costa, A. L. P., \& Silva Junior, A. C. S. (2017). Resistência bacteriana aos antibióticos e Saúde Pública: uma breve revisão de literatura. Estação Científica (UNIFAP), 7(2), 45-57. https://doi.org/10.18468/estcien.2017v7n2.p45-57

Desoti, V. C. et al. (2011). Triagem fitoquímica e avaliação das atividades antimicrobiana e citotóxica de plantas medicinais nativas da região oeste do estado do Paraná. Arquivo de Ciência da Saúde da UNIPAR, 15(1), 3-13.

Flambó, D. F. A. L. P. (2013). Atividades Biológicas dos Flavonoides: Atividade Antimicrobiana. Dissertação (Mestrado em Ciências Farmacêuticas) - Faculdade de Ciências da Saúde - Universidade de Fernando Pessoa, Porto. 46-48.

Fumagali, E. et al. (2008). Produção de metabólitos secundários em cultura de células e tecido de plantas: O exemplo dos gêneros Tabernaemontana e Aspidosperma. Revista Brasileira de Farmacognosia, 627-641. https://doi.org/10.1590/S0102-695X2008000400022

Garcia, E. D. et al. (2010). Antiedematogenic activity and phytochemical composition of preparations from Echinodorus grandiflorus leaves. Phytomedicine, 18, 80-86. https://doi.org/10.1016/j.phymed.2010.05.008

Gasparotto, F. M. et al. (2018). Heart-protective effects of Echinodorus grandiflorus in rabbits that are fed a high-cholesterol diet. Planta Medica, 84(17), 1271-1279. 
https://doi.org/10.1055/a-0644-2794

Gasparotto, F. M. et al. (2019). Antiatherosclerotic properties of Echinodorus grandiflorus (Cham. \& Schltdl.) Micheli: from antioxidant and lipid-lowering effects to an anti-inflammatory role. Journal of Medicinal Food, 22(9), 919-927. https://doi.org/10.1089/jmf.2019.0017

Gomes, F. et al. (2020). Microvascular effects of Echinodorus grandiflorus on cardiovascular disorders. Planta Medica, 86(06), 395-404. https://doi.org/10.1055/a-1118-9341

Gonçalves, A. P. S.; Lima, R. A. (2016). Identificação das classes de metabólitos secundários do extrato etanólico de Piper tuberculatum JACQ. South American, 3(2),100-109.

Lima, L. A. R. S. et al. (2011). Antifungal activity of 9-hydroxy-folianin and sucrose octaacetate from the seeds of Annona cornifolia A. St. - Hil. Annonaceae). Food Research International, 44(21), 2283-2288. https://doi.org/10.1016/j.foodres.2010.11.030

Lôbo, K. M. S. L. et al. (2010). Avaliação da atividade antibacteriana e prospecção fitoquímica de Solanum paniculatum Lam. e Operculina hamiltonii (G. Don) D. F. Austin \& Staples, do semiárido paraibano. Revista Brasileira de Plantas Medicinais, 12(2), 227-233. https://doi.org/10.1590/S1516-05722010000200016

Marques, A. M. et al. (2017). Echinodorus grandiflorus: Ethnobotanical, phytochemical and pharmacological overview of a medicinal plant used in Brazil. Food and Chemical Toxicology, 109(2),1032-1047. https://doi.org/10.1016/j.fct.2017.03.026

Mezzomo, R. et al. (2015). Utilização do tanino sobre proteína digestível não degradável de fontes protéicas em ruminantes. Acta Scientiarum: Animal Science, 37(4), 389-395.

Oliveira, N. T. O., \& Almeida, S. S. M. S. (2016). Análise fitoquímica, citotóxica e antimicrobiana do extrato bruto etanólico das folhas da espécie Ambelania acida Aublet (Apocynaceae). Biota Amazônia, 20-25. https://doi.org/10.18561/2179-5746/biotaamazonia.v6n1p26-30

Oliveira, V. B. et al. (2016). Efeito de diferentes técnicas extrativas no rendimento, atividade antioxidante, doseamentos totais e no perfil por clae-dad de dicksonia sellowiana (presl.). Hook, dicksoniaceae. Revista Brasileira de Plantas Medicinais, 18(1), 230-239. https://doi.org/10.1590/1983-084X/15_106

Penã, H. et al. (2016). VI Botânica no Inverno 2016. Instituto de Biociências da Universidade de São Paulo. Departamento de Botânica. São Paulo. 90-93.

Pereira, R. J., \& Cardoso, M. G. (2012). Metabólitos secundários vegetais e benefícios antioxidantes. Journal of Biotechnology and Biodiversity, 3(4), 146-152.

Pimenta, A. S. et al. (2006). Essential oil from two populations of Echinodorus grandiflorus (Cham. \& Schltdl.) Micheli (Chapéu de couro). Annals of the Brazilian Academy of Sciences, 78(4), 623-628. https://doi.org/10.1590/S0001-37652006000400002

Prando, T. B. L. et al. (2015). Ethnopharmacological investigation of the diuretic and 
hemodynamic properties of native species of the Brazilian biodiversity. Journal of Ethnopharmacology, 4(174), 78-369. https://doi.org/10.1016/j.jep.2015.08.029

Rebelo, A. I. M. A. (2011). Diosgenina e derivados oxidativos: potenciais agentes antitumorais e antifúngicos. Dissertação (Mestrado em Bioquímica) - Universidade da Beira Interior, Covilhã. 70-74.

Rockenbach, A. P. et al. (2018). Interferência entre plantas daninhas e a cultura: alterações no metabolismo secundário. Revista Brasileira de Herbicidas, 17(1), 59-70. https://doi.org/10.7824/rbh.v17i1.527

Rozatto, M. R. (2012). Determinação da atividade antimicrobiana in vitro de extratos, frações e compostos isolados de Arrabidaea brachypoda. Dissertação (Mestrado em Ciências Farmacêuticas) - Universidade Estadual Paulista, Araraquara. 101-102.

Santos, S. C., \& Mello, J. C. (2010). Alcaloides. In: Simões, C. M. O. (Org). Farmacognosia da planta ao medicamento. (6 ed.). Porto Alegre: UFSC. p. 765-791.

Simões, C. M. O. et al. (2017). Farmacognosia do produto natural ao medicamento. (Ed. Artemed). Porto Alegre. p. 104.

Siqueira, C. F. Q. (2011). Teores de taninos e flavonoides em plantas medicinais da caatinga: avaliando estratégias de bioprospecção. Dissertação (Mestrado em Ciências Farmacêuticas)-Centro de Ciências da Saúde - Universidade Federal de Pernambuco, Recife. 70-71.

Teixeira, C. B. (2014). Screening de plantas presente no Pantanal Sul - Mato Grossense fundamentado na atividade antimicrobiana. Dissertação (Mestrado em odontologia)-Universidade Federal do Mato Grosso do Sul, Campo Grande. 70-72.

Tiwari, P. et al. (2011). Phytochemical screening and Extraction: A Review. Internationale Pharmaceutica Sciencia, 1(1), 98-106.

Torres, D. S. et al. (2018). Influência do método extrativo no teor de flavonoides de Cnidoscolus quercifolius POHL (Euphorbiaceae) e atividade antioxidante. Química Nova, 41(7), 743-747. https://doi.org/10.21577/0100-4042.20170236

Woisky, R. G., \& Salatino, G. (1998). Analysis of propolis: some parameters and prodecodures for chemical quality control. Journal of Apicultural Research, 37(2), 99-105. https://doi.org/10.1080/00218839.1998.11100961

\section{Copyright Disclaimer}

Copyright for this article is retained by the author(s), with first publication rights granted to the journal.

This is an open-access article distributed under the terms and conditions of the Creative Commons Attribution license (http://creativecommons.org/licenses/by/4.0/). 